\title{
Exploring Children's Cultural Perceptions through Tasks Based on Films in an Afterschool Program.
}

Claudia P. Mojica

\begin{abstract}
This is a report on a finished research project that explores the cultural perceptions of children through tasks based on films in an English after-school program. This qualitative case study was carried out at a private school in Bogotá and it fostered students' active participation in the development of the classes and explored their cultural perceptions. The data collected revealed that this process of construction of the concept of culture was built by the learners from the different types of knowledge about the world, the practices, and the artifacts embedded in the community. As for the cultural perceptions that emerged in the data, these corresponded to the interpretations of students' world and life experience.
\end{abstract}

Key words: Culture, critical literacy, children's perceptions.

\section{Resumen}

Esta investigación presenta un reporte de una investigación terminada que explora las percepciones culturales de los niños, que participan en un programa de inglés informal, a partir de actividades basadas en películas. Este estudio de caso tipo cualitativo fue llevado a cabo en un colegio privado de Bogotá. El concepto de cultura adoptado desde la perspectiva de Moran (2001) es esencial para comprender el tipo de respuestas que los estudiantes dan con relación a sus mundos, creencias, valores y opiniones. Este estudio requirió de un diseño particular para la intervención pedagógica que permitió a los estudiantes participar de manera más activa en las clases y de esa forma expresar sus percepciones culturales. Los datos recogidos en este estudio permiten comprender que la articulación de las perspectivas culturales son construidas a partir de los diferentes tipos de conocimiento acerca de el mundo, las practicas que se llevan a cabo y los diferentes artefactos que el hombre ha construido en el mundo. Igualmente, las percepciones culturales corresponden a las diferentes interpretaciones y lecturas del mundo que los estudiantes han construido a través de su experiencia de vida.

Palabras Claves: Cultura, alfabetización crítica, percepciones de los niños.

\footnotetext{
* Received: 02-08-07/Accepted 09-08-07
} 


\section{Introduction}

This research took place at Fundacion Santa Maria (Foundation Holy Mary); a private school that intends to provide education for children who belong to the low socio-economic strata (1,2,3 in a scale of 1 to 6$)$. The school had an English teaching program for those children who wanted to learn English as a foreign language, but, perhaps, did not have the economic means to access such kinds of programs. This English program called the Youth Leadership Program was adopted by the school in 2003 and the author of this article participated in the construction of the program.

We started to work with movies in order to improve children's listening and oral skills; in this movie class students were exposed to listening to and reading movie captions. Afterwards, they were asked to answer some questions or work around true and false statements based on the scenes viewed. This methodology was good up to a certain period of time when students found that classes were predictable and monotonous.

Despite this, students were motivated to learn and challenged with these new elements of working on movies. It was observed that classes needed some radical changing because students felt tired of the same structure of the class (organization and type of tasks, the type of answers and so on). Therefore, the changing consisted in creating a space in which students played a more active role and developed their language abilities by means of talking about their life, their contexts, and their opinions in relation to the topics shown in the films.

\section{Research Question}

The focus of this study relies on analyzing and obtaining information about the students' cultural perceptions in regards to their own worlds, feelings and other issues that can be approached through films. In particular, we aimed at identifying the kind of perceptions and answers that children construct of cultural aspects as well as how this process can serve our context in the process of teaching and learning English as a foreign language.

In order to account for these aspects, the study posed the following main question: What do children's critical literacy practices related to the development of tasks around films tell us about their perceptions of culture? Likewise, there was a related question which aimed at giving an account of the development of students' cultural perceptions. This question was stated as follows: How do children construct their perceptions of culture? 


\section{Pedagogical Intervention}

Two main aspects were taken into account in the implementation phase of the study: task- based and critical literacy practices. Task-based approach refers to the how the classes were carried out whereas Critical Literacy Practices have to do with the what (the content of the tasks). Each task was designed in order to generate students' responses towards their own realities. Additionally, they intended to build knowledge about the world, to make sense of cultural practices that are not only international but also local, and to strengthen students' participation in the construction of themes related to their personal lives, experiences, and contexts.

In the design of the tasks, the teacher identified, through the movie, aspects that were connected with students' lives, experiences and knowledge in order to create a task that allowed the students to express, talk, inquire, exchange meaning with others and describe those aspects brought up in the movie The Lion King. An example of the kind of tasks that display how the cultural aspect and the critical literacy practices were designed can be found in Appendix 1 . This appendix shows half of the lessons that were implemented in this class.

\section{Research Design}

This is a qualitative case study intended to analyze the phenomenon of the unit of analysis by means of the description of the natural setting in which the participants of the study were interacting. Merriam (1998) points out that "qualitative research is an effort to understand situations in their uniqueness as part of their particular context and their interactions there" (p.3-5). In this research, students accounted for their perspectives of the world by means of the language. This study was not aimed at showing the linguistic development of children's proficiency; instead, the uniqueness of this case lies upon the fact that what the teacher-researcher had to do is to document and interpret the data, the answers from the students, with the objective of trying to comprehend how students understand, feel, and interpret the issues or topics embedded in the film in connection to their lives.

Three instruments- audio tape recordings, conferences, and field noteswere utilized in order to gather data and to be able to display evidence and validation of it. First, the children were audio recorded during eight sessions of the classes. Additionally, the teacher-researcher took notes of everything that went on during the classes and that could possibly shed some light on 
the questions of the research. Last, but not least, for the purpose of validation and with the idea of confirming the data collected in the first two instruments, the researcher planned some questions that guided the process of the conferences. All of the participants of this study were audio recorded during the conferences- carried out as natural and spontaneous conversations in Spanish. (See Appendix 2 ).

In the analysis of the data, the following steps were taken in order to account for validity and reliability of the data. Organization and classification of the information taking into account the different types of cultural aspects found. The indexation of the information was done based on the instrument in which it was found and the number of samples that were gathered about that cultural aspect. The identification of patterns was done by means of the repetition in which the patterns appeared in each of the instruments as well as the commonalities among them. At the end of this process, there were two categories that render for students' voices and their perceptions in light of the research questions and the theoretical framework that are portrayed in this study. Thereby, the following section will present the findings and the two categories resulting from this analysis.

Last, it is important to mention that a consent of all of the students who attended this class was gathered by means of a consent letter who was signed by the children and parents (See Appendix 3).

\section{Theoretical Framework}

There are two constructs concerning the question of this study, culture and critical literacy. I will briefly present the theoretical framework that was used in this research.

Hinkel (1999), for instance, claims that "culture is not static; it evolves as people conduct their lives and interpret their experiences in different ways" (p.77). Through this statement culture can be deemed as a concept that each individual constructs throughout life and that encompasses the various experiences that each member of a community has.

Likewise, Nieto (2002) argues that "Culture is complex and intricate; it cannot be reduced to holidays, foods or dances, although these are of course elements of culture. Everyone has a culture because all people participate in the world through social and political relationships informed by history as well 
as by race, ethnicity, language, social class, sexual orientation, gender and other circumstances related to identity and experience" ( $p, 10)$. This definition expands the understanding of the concept of culture and permits us see that it tackles everything that involves interaction with the rest of the world.

The theory of culture used in this study is found in Moran (2001): "The definition of culture relies on three interrelated dimensions, the three poles of an equilateral triangle: products, practices, perspectives... culture consists of artifacts, actions and meanings" (p. 23). Based on these components, Moran defines culture as follows: "Culture is the evolving way of life of a group of persons consisting of a shared set of practices associated with a shared set of products, based upon a shared set of perspectives on the world and a set within specific social contexts"(p. 24).

There is a connection between these three elements presented above and the kind of knowledge that is underneath and permeating the concept of culture. This knowledge, or knowings as it is defined and coined by Moran (2001), is well known by all members of the community. Hence, people behave properly in a given context, know the rules about those scenarios, and shape their own perspectives, beliefs, and values towards a product or an element of the community as well as place themselves in the world accordingly.

These four areas of knowledge help the teacher to know what students need to do when dealing with aspects of the culture. The first area, knowing about, means that the individual needs to know data or information about the products, the practices and the perspectives that are held towards a reality. The second one, knowing how, has to do with some interaction, participation or experimentation that the individual needs to have in order to learn about a specific item of the culture. The third one, knowing why, "deals with developing an understanding of fundamental cultural perspectives- the perceptions, the beliefs, values, and attitude that underline all aspects of the culture" (p. 16). The last area of knowledge, which is knowing oneself, is related to self-awareness. In this area, the most important to highlight is the learner or the individual, "they learn to understand themselves and their own culture as a means to comprehending, adapting to, or integrating into the culture" (p.17)

The other construct that needs to be addressed for the purpose of understanding the data collected in this research is concerned with critical literacy. As it was stated before, the content of the tasks aimed at connecting 
the social and cultural practices of the individuals with the themes that were broached in class. The literature maps were some aspects of what this broad concept entails.

Morgan (1997) et al. argue that "in addressing critical literacy we are concerned with the extend to which, and the ways in which, actual and possible social practices and conceptions of reading and writing enable human subjects to understand and engage the politics of daily life in the quest for a more truly democratic social order, among other things, critical literacy makes possible a more adequate an accurate reading of the world, on the basis of which, as Freire and others put it, people can enter into rewriting the world into a formation in which their interests, identities and legitimate aspirations are more fully present and are present more equally" (p:6).

This quote goes along with understanding the dynamics of critical literacy. As it can be seen, it enables our students to make and find meanings about issues of daily life that would wind up as a more significant reading of the world that surrounds their lives.

A similar definition is found in Green and Fehring (2001) who fall back on Withers so as to explain that "critical literacy...the direction of those functional skills towards the ability to mount a personal critique of all those issues which surround us as we live, learn and work- to help us understand, comment on and ultimately control the direction of our lives" (p:7).

This definition also confirms that the scope of critical literacy embraces more processes than just reading and writing. It actually helps to acknowledge the world, people, experiences, beliefs and values that are present in the daily life. Therefore, it is necessary for subjects or individuals to understand, mount a critique, and reflect about those social aspects that come about in our world and our lives.

Critical literacy has some characteristics that are worth mentioning here. Empowerment and discourse are the most relevant features that need to be addressed in order to have a better understanding of the findings of this study.

In Green (2001), it is found that "empowerment is to enable students to use their own cultural resources and to explain the relationships between school and society" (p.9). Through the use of critical literacy students are enabled to realize what their perceptions about the different realities of the world and society are. 
These practices are amply tied to the social and cultural issues that students go through their life experience. Students are empowered by means of language (oral or written) to fuel their own perceptions, ideas, beliefs, and thoughts about society and realities. The other characteristic that needs to be brought about in this theoretical framework deals with the role of discourse in the classroom.

Through discourse students are led to fully say or write their understanding of things as they think they are and find connections as regards to the reason why students think that reality is as they state it, what their real experiences are in connection to those and to learn together through dialog to nurture their perspectives.

Together with discourse, the idea of freedom of speech needs to be acknowledged and valued by teachers; otherwise, they will fall into the category of delivering knowledge or imposing ideas or beliefs. Morgan (2001) ( p 15) states that "freedom of speech is a cornerstone of democracy, in which various groups may tell their own story, their way, and be given the courtesy of a fair hearing. Hence, the citizens of such a democracy will accept their and others' form of life in their diversity as well as criticism, business, government, the media, and other aspects of public life".(p.15)

In conclusion, critical literacy provides students with the means to shape, and be heard about their own perspectives of the real life issues that surround their lives.

\section{Findings}

This article will show some samples of the different instruments used in order to present the most relevant aspects found in two categories of the analysis of data. Along with the samples, the reader will find a brief analysis of them that shed light on the questions posed in this study.

\begin{tabular}{|c|c|}
\hline Research Questions & Categories \\
\hline $\begin{array}{c}\text { What do children's critical literacy practices related to } \\
\text { the development of tasks around films tell us about their } \\
\text { perceptions of culture? }\end{array}$ & $\begin{array}{c}\text { Children's Voices and Readings about their } \\
\text { Worlds. }\end{array}$ \\
\hline How do children construct their perspectives of culture? & The Gestation Period and Birth \\
\hline
\end{tabular}




\section{Chart 1: The categories for the research questions}

The first category was named as such because it refers to how students view and read the world in which they live. Thus, in this category, the reader can find different readings, interpretations and images these children hold about different places such us the school, their home, their country, and other countries as well as people who are present in the different scenarios they live in or know. The second category was named using a metaphor that aimed to explaining that a perspective is not constructed overnight but it takes time and different elements to be shaped, exactly as the period of gestation of a human being. It takes time for a baby to be physically developed inside the womb of the mother. While the baby is being shaped, she/ he will need to be nourished. Hence, this part of the findings will also show the different elements that help constitute a perspective.

Let us start giving two samples in which students are stating either a positive or a negative reading about their parents. The first sample is taken from the field notes.

1. Two or three students came to me asking what the word influence meant, Omar ended up giving me his idea ... "Simba!! when his father says to him that he will be the king and he needs to be responsible and a good king..." then I asked my student to give a similar example with his life "my mother because she ... how do you say is sabia? She is wise and says that I need to study for the life". During this class most of the students gave as an answer that they admired their mothers and some students their fathers. Some of the reason they said in class were: because they were responsible, hard workers, honest, organized" (Field Notes, P. 18-19. SIC)

In the first sample, the role of some of the mothers in the family is perceived. There were various examples like this one that indicated that there are many mothers who are responsible for the economic part of the family. Therefore, students expressed that they admired and loved them because they faced difficult situations to bring money and pay for the basic needs of the house (rent and food).

In this sample, the students had a very high opinion of their parent(s). It seems that these opinions have been built and informed from what parents say to their children, as seen from the student's voice in this sample "she is 
wise and says that I need to study for the life"; or what students have seen or experienced in their houses about their parents' behaviour. As pointed out by Moran (2001:16), these perceptions stem from "observation, information and experiences with the culture".

In the following example, there is also a perception about a member of the students' community- his parents, but in this case the student states his opinion problematizing it.

2. Juan: no teacher, this is .... Es como algo malo no?

Teacher: so influence is something bad, give me an example

Juan : my father (students laugh)

Teacher: why your father?

Juan: Because he drinking all beer

Teacher: and he tells you to drink?

Juan: no pero si me da el ejemplo. (Audio Tape Recording, p. 10. SIC).

Through this task, students recalled a scene from the movie and identified a relationship of a bad influence in the film; then, they had to do the same using their own life experience. This task allowed students to take a critical position in the sense that they mentioned an example of the film, made a connection of their social interaction with the world, and, by means of language, expressed their perspectives, values and beliefs - these were shaped and informed by students' experience and their observation. This image is not a negative view of the student's father. Instead, it can be perceived as a problematization of his father's behavior.

In the next sample, images about places and also children's self images are presented. The sample is taken from the conferences that were done in Spanish.

Tatiana: pues me gustaría ... no quiero dejar mi país pero si me gustaría... por ejemplo que yo quiero tener una empresa entonces yo quiero tener negociaciones aquí, otras me gustaría en Francia, porque? Porque es uno de los sueños de mi mamá y yo desde hace mucho he querido conocer Francia y yo quiero cumplir ese sueño porque a mi me parece chévere. Los Estados Unidos aunque no me gusta que ahí se están urbanizando mucho sobre todo Europa. (Conferences, p. 7 SIC). 
There are several aspects that provide information as for the students' opinions and perceptions of different countries, and how this student sees and places herself in the future. There is also a sense of belonging that the student holds with Colombia "no quiero dejar mi país... quiero tener negociaciones aquí". Likewise, the student expresses her willingness to visit other countries that she finds interesting and good to visit or live in. Additionally, this willingness of visiting France, according to the student, is caused by what her mother has told her of France, as she says in the conference; this is one of her mother's dreams. It can be interpreted from this piece of data that this student shapes her opinions based upon what she has heard from people like her mother; or learnt from different means such us the school, the media, the T.V programs, the Internet, and the like. All these artifacts help us inform ourselves and thus, shape our view, readings, opinions and perspectives about the world that surrounds our lives, as it is stated by Moran in her framework of the four knowings

The following sample serves to show the different elements that a perspective needs so as to be shaped. Let us remember the name of the category gestation period and birth in order to make sense of this metaphor.

Omar: yo escogí los suricatos, pues me gustan mucho y aprendí mucho sobre los suricatos, en parte fue por el Animal Planet por el programa que se llama el reino de los Suricatos, entonces ahí muestran como ellos tienen que sobrevivir a la naturaleza.

Fernando: si es casi como una telenovela. I si le ponen nombre a cada animalito no?

Omar: y ellos principalmente lo que más les gusta hacer es cavar túneles y tienen siempre a uno que esta cuidando para avisarles a los demás por si viene el peligro, y los otros están cavando túneles y siempre se paran así en los arbolitos. Ellos corren con las cuatro patas pero utilizan dos para levantarse y ver más alto. (Conferences, p. 15. SIC)

Apparently, Omar is only talking about the meerkats and what he learnt about them. Yet, a closer and more analytic view to this sample unveils some other aspects in relation to the gestation period that the student undergoes. When one thinks of the process that students follow to articulate this perspective, some processes involved can be visualized.

First of all, the student is describing some cultural information that he learnt by means of watching a television program (what is referred in the 
literature by Moran as knowing how which means that the student knows how the meerkats function). At the same time, Omar discovers some cultural explanations about this reality (knowing about, which is obtaining some other understanding about this matter).

Then, the student develops some values and attitudes in regards to the meerkats. For example, "I like the meerkats because they are clever, organized, work in groups" (knowing why, which refers to the analysis of finding out why the student understands a reality as he does and the types of values, beliefs, or attitudes that he develops through that understanding); and, finally, the opinions, feelings and ideas generated by the previous knowledge makes him/her articulate his or her perspectives about the meerkats (knowing oneself which refers to how the person is placed towards that reality or issue- selfawareness).

By examining the process just described, students go through a process where they observe a reality, discover some facts of it, are capable of shaping some values in terms of whether they like what they have observed, experienced and learnt and finally say how they see and perceive that reality. As regards the metaphor used in the second category, it may be considered that this model proposed by Moran is somehow similar to the stages that a mother has to go through in order to deliver a baby. However, the aspect of delivering the perspectives deals with accounting for the students' answers by means of the critical literacy tasks. The exercise of expressing and giving voice to students' ideas, interpretations, and beliefs was a liberating exercise in which students' critical minds could react or hold an opinion about the social practices of everyday life.

There is an important reflection explained by Moran that connects the data here displayed. This reflection is in relation to creating spaces in which students can understand their experiences and everything surrounding them, not only for academic purposes but for their lives in general. Therefore, it is useful to create an environment where students become aware, reflect and make sense of their daily life. Concerning this, Moran (2001) states that: "Students also need to surface and give voice to the perspectives that underlie their own cultures, in particular the values, attitudes, and beliefs surrounding work and workplaces. They need, in other words, to develop the ability to interpret their experiences in cultural terms"(p.16). 
Regarding this affair, Critical Literacy tasks aided the process of validating students' voices. Thereby, one of the main characteristics of this concept is that it empowers students throughout discourse to construct their own readingcritiques of the world. The next sample emerged from one of the classes in which we were discussing the pros and cons of being an adult. As the topic was developed, the class turned into a dialogue and eventually into a debate. Students, who brought this aspect into the dialogue, lead the conversation and participated with their own experiences and knowledge. Here is the example:

C: teacher, I know that sometimes the people adult doesn't have money

$\mathrm{T}$ : yes that is true!

$\mathrm{J}$ : no consigue trabajo

L. aqui en Colombia

T. here in Colombia

L: en los Estados Unidos la mayoría tiene

Z. todos tienen plata

O: $\quad$ we don't find locos

$\mathrm{J}: \quad$ locos! Ja, ja!!

$\mathrm{J}$ : Teacher in the USA was very difficult because in one apartment.... How do you say que es muy feo... one ugly apartment is very expensive and they win more but it's very expensive at one apartment.

Ja: usted no puede asegurar que la gente sea rica!

C: when my cousing came to Colombia my brother says that he is rich but he is for example... how do you say dos botellas

T: two bottles

C. two bottles are five dollars. No teacher and for example the wife of my uncle finish the work at night and they don't have vacations and the children work (Audio recording. $\mathrm{P}$ 13. SCl)

Here, the students' voices display some values and beliefs. They had probably articulated this perspective from a long time ago primarily with the cultural knowledge of this reality -the American culture-; and the experiences or anecdotes that have happened to people who are near their lives. As the classes turned into a dialogue or debate, students were not afraid of saying and explaining things in class, for example stating whether they believe that the American dream was attainable or not. Students offered examples to illustrate their points and based on those present their cultural perspectives. Some children argue that this concept was true and some others disagreed with them by means of illustrating with their anecdotes. 
The last samples also displays how students responded to what was being said in class:

$\mathrm{JN}$ : the culture is that represent every country. Like a belch is for one country is good to belch. In Colombia for example is bad education.

$\mathrm{F}$ : for example in Arabia that in Arabia belch is for thank you, for the religious.

$\mathrm{T}$ : $\quad$ so another connotation of culture

$\mathrm{E}$ : it's a culture that has a town.

T: $\quad$ so why did you say family, Rafiky's tricks...

MF: we said family because its cultural aspects, because its important have a family and the others.

$\mathrm{T}$ : so culture is something that is important, something that represents a group of people. So for example here at Fundacion Santa Maria do people have a culture?

S: yes!!!

$\mathrm{T}$ : one example...

$\mathrm{F}$ : the Escuela Saludabe

$\mathrm{T}$ : so in your house a cultural aspect is

M: the family

S: to celebrate the birthday in the house, special days

C: we don't eat meat. Those aspects are cultural

T: why don't you eat meat?

C: only in my family who eat meat are only my uncle, osea in my family the people who don't eat meat are my mother, my brother and my sisters.

(Audio tape recording. Saturday $5^{\text {th }}$, p. 32. SCl)

As seen in the sample, the class is more like a dialogue between students and the teacher. In this dialogue, the students are in the process of making sense of what culture means and for that they rely on information that they know -belching in Arabia- about the world. Next, students use their experience as regards to the information that they know in order to illustrate that according to their experience a cultural practice can be perceived differently in Arabia and Colombia. The second issue allowed us to see that students use examples of their own contexts like the school's philosophy -La Escuela Saludable- and some affairs of their family culture such as the example of the vegetarian family.

Likewise, this entry reflects two things, the kinds of critical literacy tasks students were involved in- children brought their own cultural experiences and knowledge to account for their beliefs and values, and the way students presented their meanings and readings of the world in class- responding 
spontaneously to questions without worrying about the accuracy and acceptance of their answers in the class.

\section{Conclusions}

The objective of the main question that guided the process of this research was to explore the cultural perceptions that were evidenced in terms of the real life issues and activities students developed based on films. Regarding this question, there was a category called children's voices and readings about their worlds, in which students unveiled their perspectives in relation to people, places, products and everything that surrounds students' lives. Students expressed and took a stand towards the different elements mentioned above. Thereby, their voices reflect feelings like the admiration for their parents; problematization of some of the aspects of the culture (people, products, actions among others), descriptions about their contexts or anecdotes, and knowledge that they have acquired through different means as TV programs, the school, the Internet, or simply the things they have heard from other members of their community. These voices found in the data illustrate that students accounted, described and reflected about aspects that constitute their world (people, places, products and practices of their culture).

The second question's objective was to understand how students develop their concepts of culture through the critical literacy practices developed during the movie class. As for this, the metaphor illustrates that a perspective is similar to a baby. It requires time for it to be shaped. Nevertheless, during that period of shaping or construction of a perspective the baby feeds on some components that help to constitute it as such.

Regarding the samples and data collected, students' voices allowed to see that they had developed their perspectives throughout their life, by aspects such as observation and knowledge that children have learnt through different means. So had their individual and particular experiences in their interaction with the world helped them to gain some understanding of how the world works and hence, to construct their unique perspective about culture. These stages match the theoretical framework used in this study, Moran (2001), in terms of understanding culture itself and how we construct perspectives of it.

Therefore, the first concept that portrays the theory of culture and, hence, the understanding of how a perspective is constructed relies primarily on the 
concept of culture in itself. Recalling the definitions given in this study, Moran (2001) explains that culture is understood as: "a way of life and participating in it, therefore culture will be understood as the cultural experience- the encounter with another way of life..." (p. 13). This conception of culture leads us to make connections directly with the process in which human beings engage for building the perspectives of culture. The construction of these readings of the worlds presupposes the interaction that we have when we participate in it and conduct our lives.

The underlying point of this concept of culture springs from participation in the world we live in, the interaction with other beings, products generated by the community or nature and the practices carried on within our lives. Thus, the platform that starts and continues the ongoing process of building a perspective of culture is rooted in these three elements: interaction, participation and the experience with those products, members of the community and the practices we engaged in as was discussed throughout the analysis of the students' voices.

\section{References}

Cohen, L., \& Manion, L. (1995). Research methods in Education. New York: Routledge.

Freire, P., \& Macedo, D. (1987). Literacy: Reading the Word and the World. South Hadley, Ma: Bergin \& Garvey.

Green, P \& Fehring, H.. (2001). Critical Literacy: a Collection of Articles from the Australian Literacy Educators' Association. Australia. International Reading Association:.

Hinkel, E. (1999). Culture in Second Language Teaching and Learning. Cambridge: Cambridge University Press.

Kramsch, C. (1998). Language and Culture. Oxford University Press. New York.

Merriam, S. (1998). Case Study Research In Education: A Qualitative Approach. San Francisco. Jossey Bass Publishers.

Moran, P.(2001). Teaching Culture: Perspectives in Practice. New York: Heinle \& Heinle.

Morgan, W. (1997) Critical Literacy in the Classroom: The art of the possible. New York Routledge

Nieto, S. (2002). Language Culture and Teaching. Critical Perspectives for a New Century. New Jersey:Lawrence Erlbaum Associates. 


\section{Appendix 1}

\section{Some Content About the Tasks and Topics Developed in four Classes}

\begin{tabular}{|c|c|c|}
\hline Lesson & Aspects of culture(AC) & Tasks for Developing the AC. \\
\hline \multirow[b]{2}{*}{ Lesson 1} & a. Disobedience & $\begin{array}{l}\text { a. b. Brainstorming: Where are these issues presented } \\
\text { in the movie? }\end{array}$ \\
\hline & b. Jealousy & $\begin{array}{l}\text { a. b. Writing and Sharing: using guiding questions } \\
\text { students wrote about their life experiences in light } \\
\text { of the AC. }\end{array}$ \\
\hline \multirow{4}{*}{ Lesson 2} & a. Being an adult & b. Brainstorming: using the movie \\
\hline & b. The person I admire the most & $\begin{array}{l}\text { b. Survey: using prompts students report about this } \\
\text { aspect. }\end{array}$ \\
\hline & \multirow{2}{*}{$\begin{array}{l}\text { c. Learning key vocabulary and } \\
\text { expressions from the movie }\end{array}$} & $\begin{array}{l}\text { a. Comparing and Contrasting : differences between } \\
\text { being a child and an adult. Advantages and } \\
\text { disadvantages. Showing examples they see in } \\
\text { their families. }\end{array}$ \\
\hline & & $\begin{array}{l}\text { a. Writing examples of the use of the vocabulary in } \\
\text { my daily life. Students were asked to define the } \\
\text { expressions narrating an event they had in their } \\
\text { own lives. }\end{array}$ \\
\hline \multirow{4}{*}{ Lesson 3} & a. To be or not to be guilty & $\begin{array}{l}\text { a. Survey: students answer some questions in order } \\
\text { to remember their own experiences of this issue }\end{array}$ \\
\hline & \multirow{3}{*}{$\begin{array}{l}\text { b. Knowledge about animals of } \\
\text { Africa. }\end{array}$} & $\begin{array}{l}\text { b. Brainstorming: eliciting knowledge.Video: talking } \\
\text { about the images and information understood, } \\
\text { Group contest }\end{array}$ \\
\hline & & $\begin{array}{l}\text { a. Drawing a picture and reporting your } \\
\text { understandings or findings. }\end{array}$ \\
\hline & & $\begin{array}{l}\text { b. Discussion: using key questions students state } \\
\text { their opinions about their position concerning life } \\
\text { problems }\end{array}$ \\
\hline \multirow[b]{2}{*}{ Lesson 4} & a. Africa & \\
\hline & b. Hakunamatata philosophy & $\begin{array}{l}\text { a. Defining what culture is, Listing, examples of AC } \\
\text { found in the movie. Understanding their own } \\
\text { examples. Designing a survey. Interviewing their } \\
\text { peers and reporting on the AC they wanted to } \\
\text { explore. }\end{array}$ \\
\hline
\end{tabular}




\section{Appendix 2}

\section{Conferences}

\section{Sample Of Questions}

1. Mencionas en una de las clases que te identificabas con XXX animal, porqué crees que te identificas con ese animal? Cómo te sientes identificado con ese animal?

2. ¿Cómo te describes a ti mismo? Quién eres tú?

3. ¿Qué significa cultura para ti? Cómo se habló en la clase, crees que existe una cultura en diferentes lugares? Explica

4. ¿Crees que los eructos, la navidad, la música son aspectos culturales? ¿Por qué?

5. ¿Cuál es la idea o concepto que tienes con respecto a África? En términos de gente, lenguaje, costumbres, tradiciones, escenarios...

6. ¿Qué piensas acerca de la filosofía de la canción? Qué haces cuando tienes problemas?

7. ¿Quién es tu mejor amigo? ¿Por qué? ¿Qué es un amigo?

8. ¿Qué tipo de castigos has tenido? ¿Por qué? 


\section{Appendix 3}

\section{Consent Letter}

Bogotá, D.C. 4 de Junio 2005

\section{Señores}

\section{Padres de Familia}

Programa Lideres Juveniles de La Fundación Santamaría

\section{Queridos padres de Familia:}

Queremos solicitarle su consentimiento para llevar a cabo una investigación con énfasis en el proceso de aprendizaje de inglés dentro del programa. Esta investigación quiere identificar el tipo de percepciones culturales que los niños producen durante el desarrollo de la clase con Películas en inglés. La participación de las personas es completamente voluntaria.

De ante mano les queremos hacer saber que los nombres de sus hijos se manejaran con nombres ficticios para proteger su privacidad. Los niños serán entrevistados, filmados y sus voces serán grabadas en muchas de las clases. Esta investigación pretende dar cuenta de los procesos que se siguen dentro de esta clase, y al mismo tiempo mejorar muchos aspectos dentro de estas clases.

Gracias por su colaboración.

Claudia Patricia Mojica

Docente e Investigadora.

Firme esta lista si está dispuesto a participar y dejar que su hijo o hija participe en este proyecto de investigación

\section{THE AUTHOR}

Claudia P. Mojica holds a B.A in philology and Languages from Universidad Nacional de Colombia. She is currently a candidate in the Masters Program in Applied Linguistics at Universidad Distrital. She is working as a teacher at Universidad Nacional de Colombia and Coorporación Universitaria Minuto de Dios. She has been a teacher for public and private universities un Bogotá since 2003. E-mail:claudiapmojica@yahoo.com 